\title{
Allogenic bone narrow transplantation in sickle-cell diseases.
}

\author{
Belinda Pinto Simões ${ }^{1 *}$, Fabiano Pieroni1, Thalita Costa ${ }^{1}$, George Navarro Barros ${ }^{1}$, Guilherme Darrigo Jr. ${ }^{1}$, Carlos Settani \\ Grecco $^{1}$, Juliana Elias Bernardes ${ }^{1}$, Daniela Moraes ${ }^{1}$, Ana Beatriz Lima Stracieri ${ }^{1}$, Renato Cunha ${ }^{1}$, Maria Carolina Rodrigues ${ }^{1}$
}

\section{SUMMARY}

\begin{abstract}
Sickle-cell diseases are the most common inherited hemoglobinopathies worldwide. Improvement in survival has been seen in the last decades with the introduction of careful screening and prevention of complications and the introduction of hydroxyurea. Stem-cell transplantation is currently the only curative option for these patients and has been indicated for patients with neurological events, repeated vaso-occlusive crisis, any organ damage or presence of red blood cell antibodies. Related bone-marrow or cord-blood transplant has shown an overall survival of more than $90 \%$ with a disease-free survival of $90 \%$ in 1,000 patients transplanted in the last decades. The use of unrelated donors unfortunately has not shown the same good results, but better typing methods and improved support may improve the outcome with this source of stem cells in the future. In Brazil, only recently stem cell transplant from related donors has been included in the procedures performed in the public health system. The use of related bone marrow or cord blood and a myeloablative conditioning regimen are considered standard of care for patients with sickle-cell diseases. Transplants with non-myeloablative regimens, unrelated donors or haploidentical donors should be performed only in controlled clinical trials.
\end{abstract}

Keywords: Sickle Cell Disease; Stem Cell Transplantation; Hemoglobinopathies.

\section{INTRODUCTION}

Hemoglobinopathies constitute the most frequent monogenic diseases. It is estimated that approximately 300,000 children are born annually with some type of hemoglobinopathy, with sickle-cell diseases being the most common of them, accounting for over $80 \%$ of these cases. ${ }^{1}$ However, these figures are underestimated, considering that they often come from retrospective data of individual institutions and not from neonatal screening programs.

In Brazil, it is estimated that $4 \%$ of the population is a carrier of the $\mathrm{S}$ gene, a number that could reach $10 \%$ in Afro-descendants. Sickle-cell disease is caused by a mutation, resulting in a mutant beta protein called hemoglobin $\mathrm{S}(\mathrm{HbS})$. In $\mathrm{HbS}$, there is an exchange of an amino acid at position 6 , replacing glutamic acid by valine. In homozygous form or in combination with other hemoglobinopathies, deoxygenated $\mathrm{HbS}$ form polymers that make the cell rigid, less deformable and that sometimes damages the cell membrane, leading to hemolytic anemia. ${ }^{2}$ Disease severity depends on the genotype, with the most severe form being the homozygous one for $\mathrm{HbS}$ (HbSS), i.e., sickle-cell anemia. Combinations with thalassemia may be milder in cases of persistence of some normal beta chain production $(\mathrm{HbS} \beta+)$ or more similar to the homozygous form, if there is no production of the normal beta chain $(\mathrm{HbS} \beta 0)$. Other combinations, such as with hemoglobinopathy $\mathrm{C}$, the HbSC, usually have a milder clinical picture (Table 1). From a pathophysiological point of view, the repeated vaso-occlusive crises lead to tissue infarction in several organs. The interaction of circulating cells and altered vascular endothelium of patients with sickle-cell disease also plays an important role in the disease pathophysiology. ${ }^{2}$

Sickle-cell diseases are systemic diseases that result in damage to all organs. The clinical picture evolution is extremely unpredictable and can vary from mild to severe forms as early as in childhood. ${ }^{2}$ The most common complications are vaso-occlusive crises that can occur anywhere, but are more common in the bone marrow, causing intense bone pain; in the lung, as the so-called acute chest syndrome and in the central nervous system. Strokes are especially feared and may be apparent or silent, being related to high morbidity and mortality. ${ }^{3}$ Neurological complica- 


TABLE 1. Common genotypes and severity of sickle cell diseases
\begin{tabular}{lllll} 
Genotype & Abbreviation & Name & Hb $(\mathrm{gdL})$ & Severity \\
\hline$\beta^{\mathrm{s}} / \beta^{\mathrm{s}}$ & $\mathrm{HbSS}$ & Sickle-cell anemia & $6-9$ & ++ \\
\hline$\beta^{\mathrm{s}} / \beta^{0}$ & $\mathrm{HbS} \beta^{0}$ & S-beta thalassemia & $6-9$ & +++ \\
\hline$\beta^{\mathrm{s}} / \beta^{\mathrm{C}}$ & $\mathrm{HbSC}$ & SC hemoglobinopathy & $9-12$ & ++ \\
\hline$\beta^{\mathrm{s}} / \beta^{+}$ & $\mathrm{HbS} \beta^{0}$ & S beta talassemia & $10-13$ & + \\
\hline
\end{tabular}

tions, such as silent infarctions, transient ischemic attacks (TIA), ischemic or hemorrhagic strokes have a prevalence of approximately $5 \%$ in children with $\mathrm{HbSS}$ and $\mathrm{HbS} \beta 0$. Strokes occur in up to $10 \%$ of children with HbSS, with risk factors being a previous TIA, low hemoglobin levels, increased vascular flow on transcranial Doppler ${ }^{4}$ Recurrence of cerebral ischemic events occurs in 60 to $90 \%$ of patients that do not receive secondary prophylaxis measures (chronic transfusions, bone marrow transplantation). ${ }^{5}$ Repeated splenic infarctions lead to organ atrophy (autosplenectomy), with subsequent splenic hypofunction. ${ }^{6}$

The treatment consists of the introduction of antibiotic prophylaxis as soon the diagnosis is made and family guidance regarding the care and recognition of more severe pictures, preventing dehydration and hypo-oxygenation. ${ }^{2}$ The use of hydroxyurea, a drug able not only to increase fetal hemoglobin levels, but also to reduce leukocytes and inflammatory mediators has changed the natural history of the disease. Its use has been recommended from early childhood in order to prevent irreversible organ damage. ${ }^{7}$

Despite these advances in the treatment of sickle-cell disease, some patients do not show adequate responses to hydroxyurea and may develop severe complications at a young age. The great challenge has been to identify predictors of severity that can be used to stratify patients for different types of treatment earlier. Some factors such as persistently lower hemoglobin and severe dactylitis have been associated with worse clinical outcome.

Other markers, such as increased lactate dehydrogenase, as a result of hemolysis, has also been associated with more severe clinical pictures. Although these risk factors are already known, not all of them are accurate enough to guide the therapeutic decision-making. ${ }^{8}$ Currently, the most important factor from the clinical point of view is the alteration in the transcranial Doppler, which is a predictor of vascular lesion in the central nervous system. ${ }^{5}$ Early and routine use of ultrasound assessment can predict the occurrence of stroke, leading to changes in the therapeutic strategy. ${ }^{9}$

\section{INDICATIONS OF ALLOGENEIC BMT IN SICKLE-CELL DISEASES}

The first facts and the vast majority of currently available data on allogeneic BMT in sickle-cell disease (SCD) are on children. The age of 16 years, which appears in several older publications, is derived from rationale on allogeneic BMT in thalassemia. Children with thalassemia major that receive chronic transfusions since the first months of life will have a significant iron accumulation if not submitted to adequate iron chelation. Therefore, the Pesaro group demonstrated that inadequate iron chelation and liver alterations, especially hemosiderosis, led to inferior BMT outcomes..$^{10}$ Children older than 16 years, due to the prolonged time of transfusion and consequent accumulation of iron in the 1990s, consequently had these inferior outcomes after BMT. Therefore, restrictions regarding BMT in patients with thalassemia were then assumed for patients with sickle-cell disease (SCD). The pathophysiology of sickle-cell diseases, however, can be very different and the clinical outcome is not as predictable as in the constant iron accumulation. For this reason, the vast majority of data on allogeneic BMT in SCD are obtained from children. Additionally, children with SCD had, at the time, few therapeutic options beyond the general and antibiotic prophylaxis measures. Considering the unpredictability of the clinical course and few predictive factors of severity, it is presumed as a rule that only patients with unfavorable evolution and some organ damage must undergo allogeneic BMT.

Table 2 shows the main indications for allogeneic BMT recognized by international BMT Societies. ${ }^{11,12}$ All of them agree that all patients with symptomatic disease and that has an identical HLA donor should be transplanted as soon as possible. Other tools, such as the routine use of transcranial Doppler (TCD) in the early evaluation of cerebral blood flow alterations can be crucial to identify patients that can benefit from allogeneic BMT before irreversible symptoms or lesions occur. Therefore, in addition to the presence of organ damage in both the central nervous system or another organ and an unfavorable evolution with repeated vaso-occlusive crises, it is accepted today the transplantation of patients with TCD alterations. Another indication would be the increase in tricuspid valve regurgitation velocity $\geq 2.7 \mathrm{~m} / \mathrm{sec}$ at the conventional echocardiography, as it indicates the need for catheterization assessment for possible pulmonary hypertension. ${ }^{13}$ 
TABLE 2. Alo BMT indications according to the North American groups of BMT (CIBMTR) and the European Group of BMT (EBMT)

Established Alo BMT indications

Stroke

Isquemia Cerebral

Cerebral ischemia - neurological event lasting $>24$ hs

Velocity in TCD $\geq 200 \mathrm{~m} / \mathrm{s}$

Repeated Thoracic Syndromes

Recurrent priaprism

Allosensitization

Osteonecrosis

Sickle-cell nephropathy

\section{Allogeneic bone marrow transplantation}

bone marrow transplantation is currently the only curative option for patients with sickle cell disease and aims to restore normal hematopoiesis and thus prevent damage by successive sickling episodes. The first description of allogeneic bone marrow transplantation for the treatment of sickle cell anemia dates from 1984, in a patient with acute leukemia. ${ }^{14}$ This transplantation showed it was possible to cure SCD patients with this therapy. After this first report, two groups in the USA and Belgium published the first series of patients with sickle-cell disease submitted to allogeneic BMT, with overall survival outcomes $>90 \%$ and event-free survival $>85 \%{ }^{15,16}$

\section{Myeloablative Conditioning}

Large part of the initial data comprises myeloablative conditioning and related donors. The first two series are from the Belgian group in 1996 and the North-American group in 1998 (Table 2). ${ }^{15,17}$ After these first publications, other groups reported similar experiences. ${ }^{18-20}$ The most often used regimen was the one with busulfan $16 \mathrm{mg} / \mathrm{kg}$ and cyclophosphamide $200 \mathrm{mg} / \mathrm{kg}$ with or without antithymocyte globulin (ATG) or anti-CD52 antibody (Alemtuzumab). More recently, the introduction of Treosulfan and Thiotepa showed similar efficacy with a slightly superior safety profile related to early complications, such as sinusoidal obstruction syndrome.

The data, however, are similar in terms of overall survival and event-free survival. ${ }^{21}$ Table 3 shows the data of the largest published series with myeloablative regimen and identical HLA (human leucocyte antigen) sibling donors. These data clearly demonstrate the benefit of allogeneic bone marrow transplantation in the treatment of patients with sickle-cell disease. Low mortality related to BMT and the low incidence of both acute (aGVHD) and chronic (cGVHD) graft-versus-host-disease (GVHD) demonstrate the curative potential of this therapeutic approach, as well as its safety.
The largest sample of allogeneic BMT in patients with sickle-cell disease was recently presented in a congress. ${ }^{22}$ One thousand transplantation cases were reviewed in the USA, Europe and Brazil. The transplants were carried out in 90 centers from 23 countries. All patients received transplantation from an identical HLA sibling donor. The median age was 9 years (1-54 years) and $85 \%$ of patients were younger than 16 years. More than half of transplantations, 53\%, were carried out after 2007. Most patients had HbSS and stroke was the most common indication for BMT. Regular transfusions and use of hydroxyurea were carried out in $93 \%$ and $53 \%$ of patients, respectively, pre allogeneic BMT. The most commonly used conditioning regimen was myeloablation $(87 \%)$ and the most widely used regimen consisted of busulfan and cyclophosphamide. The source of hematopoietic stem cells was the bone marrow in $85 \%$ of cases.

The median follow-up time was 45 (1.1-324.6) months. Twenty-six patients had primary graft failure and 47 had late graft loss. The probability of overall survival and event-free survival at 3 years was respectively 94\% (95\% CI: 92-95) and 90\% (95\%CI 68-82). The use of peripheral blood hematopoietic stem cells was significantly associated with worse overall survival (BM $94 \%$ vs. PB $80 \%, p<0.0001)$. Death occurred in $6.7 \%$ of patients primarily due to infection or GVHD. At the multivariate analysis, each year of age (HR 1.1, 95\% CI: $1.07-1.14, p<0.001)$ and the use of peripheral blood (HR 3:43, 95\% CI: $1.49-7.88, p=0.004)$ were associated with higher mortality.

The use of a myeloablative regimen in the univariate analysis was associated with better event-free survival ( $91 \pm 1 \%$ vs. $82 \pm 1 \%$, respectively; $\mathrm{p}<0.001$ ). The confidence interval for aGVHD grades $2-4$ was $14.4 \%$ (12.2-16.7) and for chronic GVHD it was $13.3 \%$ (11-15.8). This large series demonstrates the efficacy and safety of allogeneic BMT in patients with sickle-cell disease, even in established lesions. Thus, the allogeneic BMT with identical HLA sibling donor and myeloablative conditioning is now considered the treatment of choice and routine for individuals with sickle-cell disease with indication for BMT. The use of intravenous busulfan should always be the route of choice and the bone marrow should be the source of hematopoietic stem cells.

Some specific care of these patients is important, such as the maintenance of anticonvulsants throughout the period of calcineurin inhibitor use (preferably Lamotrigine, as it does not interfere with serum cyclosporine levels), maintaining platelet levels throughout the BMT period $>50,000 / \mu \mathrm{L}$, maintaining hemoglobin levels bet- 
ween 9 and $11 \mathrm{~g} / \mathrm{dL}$ and no higher, maintaining adequate levels of magnesium and be quite assertive regarding blood pressure control.

\section{NON-MYELOABLATIVE CONDITIONING}

The idea that a mixed chimerism would be enough to prevent the vaso-occlusive crises and the fear of submitting patients already showing extensive organ lesions to transplantation with myeloablative regimens, especially adult ones, has made several non-myeloablative regimens be tested in patients with sickle-cell disease. The first results, more often seen in case reports than in series of patients, were quite disappointing with high engraftment failure rate and delayed engraftment loss. On the other hand, more recent series with better support measures and new conditioning regimens (see Table 4) have started to show better results.

The most recent series with better immunoablative regimens have shown results that are superior to those published in previous decades, with lower rates of rejection and low toxicity. Several groups have tested different conditioning regimens, with the greatest experience being that of the US group with low grafting failure rate and excellent overall survival and event-free survival. ${ }^{23,24}$ However, it is known that some of these patients require immunosuppressive maintenance to keep the grafting ${ }^{23}$.
Therefore, transplantation with non-myeloablative conditioning should still be considered only in clinical trials and should not be indicated as routine.

\section{SOURCES OF ALTERNATIVE HEMATOPOIETIC STEM CELLS}

The exceptional outcomes with related donors resulted in the search for the cure of the disease with alternative donors. The use of related cord blood, despite showing a delayed neutrophil and platelet engraftment, subsequently showed in the largest series published by the European group of BMT (EBMT), a disease-free survival after 6 years of follow-up $90 \%$, comparable with that of related BM. ${ }^{22}$ Also, the data from these 90 cases showed no difference in terms of overall and event-free survival when compared with bone marrow use. ${ }^{22}$ Therefore, the use of related umbilical cord blood can be also considered a source of hematopoietic stem cells for allogeneic BMT in sickle-cell disease.

In turn, the use of unrelated umbilical cord blood did not show satisfactory results. The graft rejection rate was $46 \%$ in two studies. Although the overall survival rate was $94 \%$, the incidence of aGVHD was $20 \%$, much higher than that found in related umbilical cord blood. ${ }^{25}$ The use of unrelated cord blood must be considered only in clinical trials.

TABLE 3. Main series of myeloablative allogeneic BMT with related donor for treatment of sickle-cell diseases.

\begin{tabular}{llllllll} 
Author & Vermylen & Walters & Bernaudin & Panepinto & Lucarelli & Mc Pherson & Locatelli \\
& 1998 & 1996 & $2007-2010$ & 2007 & 2012 & 2011 & 2013 \\
\hline $\mathrm{N}$ & 50 & 26 & 121 & 67 & 40 & 27 & 160 \\
\hline Overall survival & $96 \%$ & $94 \%$ & $98 \%$ & $97 \%$ & $91 \%$ & $96 \%$ & $97 \%$ \\
\hline Sobrevida Livre de Eventos & $82 \%$ & $84 \%$ & $95 \%$ & $85 \%$ & $91 \%$ & $96 \%$ & $88 \%$ \\
\hline BRM $^{*}$ & $7 \%$ & $6 \%$ & $7 \%$ & $0 \%$ & $9 \%$ & $4 \%$ & $4,5 \%$ \\
\hline Grafting failure & $10 \%$ & $10 \%$ & $7 \%$ & $13 \%$ & $0 \%$ & $0 \%$ & $7 \% \mathrm{MO} 10 \% \mathrm{SCU}$ \\
\hline Idades & $1-23$ & $3-15$ & $2-22$ & $2-27$ & $2-17$ & $3-17$ & $3-17$ \\
\hline aGVHD & $20 \%$ & $3 \%$ & $17 \%$ & $10 \%$ & $17,5 \%$ & $12 \%$ & $21 \% \mathrm{MO} 11 \% \mathrm{SCU}$ \\
\hline cGVHD $^{* * *}$ & $10 \%$ & $3 \%$ & $11 \%$ & $22 \%$ & $5 \%$ & $4 \%$ & $12 \% \mathrm{MO} 5 \%$ SCU \\
\hline
\end{tabular}

BRM - BMT-related mortality; aGVHC - acute graft versus host disease

${ }^{* * *}$ cGVHD - chronic graft versus host disease; UCB - umbilical cord blood; BM: bone marrow

\begin{tabular}{|c|c|c|c|c|c|c|}
\hline Author & $\begin{array}{l}\text { Van Besien } \\
2000\end{array}$ & $\begin{array}{l}\text { lannone } \\
2003\end{array}$ & $\begin{array}{l}\text { Hsie H } \\
2009\end{array}$ & $\begin{array}{l}\text { King AA } \\
2015\end{array}$ & $\begin{array}{l}\text { Saraf S } \\
2016\end{array}$ & $\begin{array}{l}\text { Strocchio } \\
2015\end{array}$ \\
\hline $\mathrm{N}$ & 2 & 6 & 30 & 43 & 13 & 15 \\
\hline Overall survival & 1 caso & $100 \%$ & $97 \%$ & $93 \%$ & $100 \%$ & $100 \%$ \\
\hline Event-free survival & 1 caso & $0 \%$ & $87 \%$ & $90 \%$ & $92 \%$ & $93 \%$ \\
\hline $\mathrm{BRM}^{*}$ & $50 \%$ & $0 \%$ & $4 \%$ & $5,7 \%$ & 0 & 0 \\
\hline Grafting failure & $0 \%$ & $100 \%$ & $13 \%$ & 1 Case SCU & $8 \%$ & $7 \%$ \\
\hline Ages & 40 e 56 & $3-20$ & $17-65$ & $0,8-20$ & $17-40$ & $<16$ \\
\hline $\mathrm{aGVHD} * *$ & 1 caso grave & - & 0 & $23 \%$ & 0 & \\
\hline $\mathrm{cGVHD}^{* * *}$ & - & - & 0 & $13 \%$ & 0 & \\
\hline
\end{tabular}

BRM - BMT-related mortality; aGVHC - acute graft versus host disease

${ }^{* * *}$ cGVHD - chronic graft versus host disease; UCB - umbilical cord blood 
The first obstacle of using unrelated donors is finding the donors for these patients. The probability of finding donors in this group is significantly lower than in Caucasians populations and is only $19 \%$ at allelic level. ${ }^{25}$ Therefore, there are few data with unrelated donors in the literature and there are only studies in progress, without definitive results. This source should be considered only in clinical trials and cannot be recommended for routine use.

The introduction of haploidentical allogeneic BMT with the use of cyclophosphamide after hematopoietic stem cell infusion has dramatically increased the availability of donors for patients with hematological malignancies. With the favorable data and the low incidence of aGVHD and cGVHD, the first data on hemoglobinopathies appeared. The Johns Hopkins group described the first 14 cases, aged 15 to 42 years, who were transplanted with haploidentical related donors. With a median follow-up of two years, 11 patients maintained a stable graft (14 haploidentical and 3 related donors) and in 6 cases it was possible to discontinue immunosuppression. Although there were no deaths in the described cases, 6 of 14 patients had graft rejection. ${ }^{26}$ The group has been carrying out minor protocol modifications to allow better grafting in patients with non-malignant diseases. Nevertheless, the allogeneic
BMT with related haploidentical donors should be performed only in the context of a clinical trial.

Table 5 summarizes the main series with alternative hematopoietic stem cell sources. ${ }^{25}$

\section{ThE TREATMENT OF SICKLE-CELL DISEASES IN BRAZIL}

Brazil has a comprehensive public health system (SUS) legislation regarding the treatment of sickle-cell diseases. Even though these were initiated only after 2005, several decrees have been published, covering different aspects of the treatment of these individuals. Table 6 summarizes the main decrees published regarding the treatment of patients with sickle-cell disease. Despite this comprehensive legislation, access to this type of treatment is still very irregular in different parts of the country. The socioeconomic status of the population also hinders access to all available treatments through SUS. ${ }^{27}$

The introduction and scope of the neonatal screening program (NSP) in the whole country after 2014 has not resulted yet in improved survival for patients with sickle-cell diseases in Brazil. ${ }^{28}$ Nonetheless, the introduction of allogeneic BMT as a therapeutic option in SUS for patients with sickle-cell diseases was a step forward in the

TABLE 5. Outcomes of unrelated or haploidentical allogeneic BMT in individuals with sickle-cell diseases

\begin{tabular}{|c|c|c|c|c|c|c|c|}
\hline Author & $\mathrm{N}$ & Mean age & HST source & OS (\%) & Rejection & DFS & BRM \\
\hline Bolanos-Maede & 14 & 22 & Haplo & 100 & $43 \%$ & $57 \%$ & 0 \\
\hline Dallas & 8 & 9 & Haplo & 75 & $38 \%$ & $38 \%$ & 38 \\
\hline De la Fuente & 13 & 10 & Haplo & 94 & & & \\
\hline Eckrich & 15 & & CD34 & 75 & $7 \%$ & $67 \%$ & \\
\hline Kamani & 8 & 13,7 & Cord & 87 & $63 \%$ & $37 \%$ & 13 \\
\hline Ruggeri & 16 & 6 & Cord & 94 & - & $50 \%$ & 6 \\
\hline Shenoy & 29 & 14 & $\mathrm{BM}$ & 86 & $10 \%$ & $76 \%$ & 21 \\
\hline
\end{tabular}

HST: hematopoietic stem-cell; BM: bone marrow; Haplo: haploidentical donor

\section{TABLE 6. Ministry of Health Decrees related o sickle-cell diseases in Brazil}

\begin{tabular}{|c|c|}
\hline Decrees & Description \\
\hline $\begin{array}{l}\text { Decree n. 1.391/GM of August } \\
16,2005\end{array}$ & $\begin{array}{l}\text { Institutes, within the National Health System, the guidelines for the National Comprehensive Care Policy } \\
\text { for People with sickle cell disease and other hemoglobinopathies. }\end{array}$ \\
\hline $\begin{array}{l}\text { Decree n. 12.104, of December } \\
1,2009\end{array}$ & $\begin{array}{l}\text { Provides for the establishment of the National Action Day for the Rights of People with Sickle Diseases, to } \\
\text { be celebrated annually on October } 27 .\end{array}$ \\
\hline Decree n. 55, of January 29, 2010 & $\begin{array}{l}\text { Approved the Clinical Protocol and Therapeutic Guidelines - Sickle Cell Disease, considering the need to } \\
\text { improve Sickle Cell Disease parameters in Brazil and to update national guidelines for the diagnosis and } \\
\text { monitoring of patients with this disease. Hydroxyurea for patients with }>3 \text { years. }\end{array}$ \\
\hline Decree n. 1459, of June 24, 2011 & $\begin{array}{l}\text { Institutes, within the Brazilian Unified Health System - SUS - the Stork Network. In December 2013, } \\
\text { through a technical communication, hemoglobin electrophoresis was included in the prenatal screening in } \\
\text { the Stork Network. }\end{array}$ \\
\hline Decree n. 473, of April 26, 2013 & $\begin{array}{l}\text { Establishes the protocol for Transcranial Doppler use as an outpatient procedure in stroke prevention in } \\
\text { patients with sickle-cell disease. }\end{array}$ \\
\hline Decree n. 27, of June 12, 2013. & Incorporates hydroxyurea in children with sickle-cell disease in the Brazilian Unified Health System - SUS. \\
\hline $\begin{array}{l}\text { Decree n. 1321, of December 21, } \\
2015 .\end{array}$ & $\begin{array}{l}\text { Includes in the list of Procedures, Drugs, Orthoses, Special Prostheses and Materials of SUS, the compatibility } \\
\text { of allogeneic transplant with related donor of bone marrow, peripheral blood or umbilical cord blood for the } \\
\text { treatment of sickle cell disease, and establishes guidelines and type of transplantation for this purpose. }\end{array}$ \\
\hline
\end{tabular}


fight against this not so benign disease. Table 7 depicts the codes to be used for billing purposes in SUS.

Decree N. 1321 of December 21, 2015, summarized in Table 8, includes in the Technical Regulations of the National Transplant System, the indication for allogeneic transplantation with related donor of bone marrow, peripheral blood or umbilical cord blood, with myeloablative regimen, for the treatment of sickle-cell disease.

According to the decree, the allogeneic hematopoietic stem cell transplantation (HSCT) with related donor, of bone marrow, peripheral blood or umbilical cord blood, with myeloablative regimen, for the treatment of sickle-cell disease may be indicated and performed in patients who meet the following criteria:

I-Patient aged up to 16 years with sickle-cell disease type $S$, homozygous or type S beta thalassemia (Sbeta) using hydroxyurea, with at least one of the following conditions:

a. neurological alterations due to stroke, neurological alteration that persists for more than 24 hours or alterations at imaging tests;

\begin{tabular}{|c|c|c|}
\hline SUS code & Source & ICD \\
\hline $05.05 .01 .001-1$ & $\begin{array}{l}\text { Allogeneic BMT with } \\
\text { related donor }\end{array}$ & $\begin{array}{l}\text { D57.0 Sickle-cell } \\
\text { anemia with crisis } \\
\text { D57.2 Double } \\
\text { heterozygous } \\
\text { sickle cell disorders }\end{array}$ \\
\hline $05.05 .01 .003-8$ & $\begin{array}{l}\text { Allogeneic } \\
\text { transplantation with } \\
\text { related donor of } \\
\text { umbilical cord blood }\end{array}$ & $\begin{array}{l}\text { D57.0 Sickle-cell } \\
\text { anemia with crisis } \\
\text { D57.2 Double } \\
\text { heterozygous } \\
\text { sickle-cell disorders }\end{array}$ \\
\hline $05.05 .01 .005-4$ & $\begin{array}{l}\text { Allogeneic } \\
\text { transplantation } \\
\text { with related donor } \\
\text { of peripheral } \\
\text { hematopoietic stem cells }\end{array}$ & $\begin{array}{l}\text { D57.0 Sickle-cell } \\
\text { anemia with crisis } \\
\text { D57.2 Double } \\
\text { heterozygous } \\
\text { sickle-cell disorders }\end{array}$ \\
\hline
\end{tabular}

TABLE 8. Indications for allogeneic BMT with related donor according to decree n. 1321 of December 21, 2015'

Patient aged up to 16 years old with homozygous sickle cell disease type $\mathrm{S}$ or type $\mathrm{S}$ beta thalassemia (Sbeta) using hydroxyurea that has at least one of the following conditions.

a. Neurological alteration due to stroke, neurological alteration that persists for more than 24 hours or alteration at imaging assessment;

b. cerebrovascular disease associated with sickle cell disease;

c. more than two severe vaso-occlusive crises (including Acute

Thoracic Syndrome - ATS) in the previous year;

d. more than one episode of priaprism;

e. presence of more than two antibodies in patients undergoing

hypertransfusion or one high-frequency antibody;

f. osteonecrosis in more than one joint. b. cerebrovascular diseases associated to sickle-cell disease;

c. more than two severe vaso-occlusive crises (including Acute Thoracic Syndrome - ATS) in the last year;

d. more than one episode of priapism;

e. presence of more than two antibodies in patients submitted to hypertransfusion or one high-frequency antibody; or

f. osteonecrosis in more than one joint.

The use of hematopoietic stem cell sources bone marrow, peripheral blood or umbilical cord blood) should consider the risks to the donor and the risks and benefits to the recipient.

\section{Conclusions}

A better understanding of the pathophysiology of sickle-cell disease has brought significant advances to the treatment of these individuals. Early identification of affected individuals by neonatal screening, the introduction of drug preventive measures, such as antibiotic prophylaxis and hydroxyurea and careful monitoring of patients could provide important benefits in terms of survival. Allogeneic BMT with related donors is still the only curative option for sickle-cell disease and has shown excellent results. The incorporation of allogeneic BMT into the Brazilian public health system, SUS, will provide patients with organic complications and patients with an unfavorable evolution with a real hope of cure. Unfortunately, there are no clear predictors of unfavorable evolution that may predict patients who will benefit most from the procedure, but all affected patients that show more severe signs of evolution should be tested to search for possible donor in the family. Universal access to available treatment and follow-up assessment to all patients with sickle-cell disease is still a major challenge in our country.

\section{Resumo}

Transplante alogênico de medula óssea em doenças falciformes

As doenças falciformes são as hemoglobinopatias mais frequentes mundialmente. Nas últimas décadas vivenciamos melhora na sobrevida de portadores destas patologias com a introdução de medidas preventivas e o uso precoce da hidroxiurea. O transplante de medula óssea alogênico (alo TMO) é a única opção terapêutica curativa para as hemoglobinopatias. O mesmo tem sido indicado para pacientes com complicações neurológicas, crises vasoclusivas repetidas, alguma lesão orgânica e alosensibilizados. O uso de doadores 
relacionados de medula óssea ou cordão umbilical mostrou em 1000 procedimentos realizados sobrevida global de 95\% e sobrevida livre de ventos de $90 \%$. O uso de doadores não aparentados não mostrou resultados tão expressivos, mas no futuro métodos melhores de tipagem de HLA e de medidas de suporte podem melhorar estes resultados. No Brasil apenas recentemente o alo TMO foi incluído no âmbito do sistema único de saúde (SUS) como opção terapêutica para portadores de doenças falciformes. O uso de doadores aparentados de $\mathrm{MO}$ ou de SCU com regime mieloablativo é considerado hoje tratamento estabelecido, sendo que o uso de doadores alternativos não aparentados ou haploidenticos e o uso de transplante com regime não mieloablativo deve ser considerado apenas em estudos clínicos.

Palavras-Chave: Anemia Falciforme; Transplante de Medula Óssea; Hemoglobinopatias

\section{REFERENCES}

1. Weatherall DJ. The inherited diseases of hemoglobin are an emerging global health burden. Blood. 2010;115(22):4331-6.

2. Rees DC, Williams TN, Gladwin MT. Sickle-cell disease. Lancet. 2010;376(9757):2018-31.

3. Fasano RM, Meier ER, Hulbert ML. Cerebral vasculopathy in children with sickle cell anemia. Blood cells, Blood Cells Mol Dis. 2015;54(1):17-25.

4. Switzer JA, Hess DC, Nichols FT, Adams RJ. Pathophysiology and treatment of stroke in sickle-cell disease: present and future. Lancet Neurol. 2006;5(6):501-12.

5. Webb J, Kwiatkowski JL. Stroke in patients with sickle cell disease. Expert Rev Hematol. 2013;6(3):301-16.

6. Brousse V, Buffet P, Rees D. The spleen and sickle cell disease: the sick(led) spleen. Br J Haematol. 2014;166(2):165-76.

7. Field JJ, Nathan DG. Advances in sickle cell therapies in the hydroxyurea era. Mol Med. 2014;20 (Suppl 1):S37-42.

8. Quinn CT. Minireview: Clinical severity in sickle cell disease: the challenges of definition and prognostication. Exp Biol Med. 2016;241(7):679-88.

9. Lobo CL, Cancado RD, Leite AC, Dos Anjos AC, Pinto AC, Matta AP, et al. Brazilian Guidelines for transcranial doppler in children and adolescents with sickle cell disease. Rev Bras Hematol Hermoter. 2011;33(1):43-8.

10. Lucarelli G, Galimberti M, Polchi P, Angelucci E, Baronciani D, Durazzi $\mathrm{SM}$, et al. [Bone marrow transplant in thalassemia. The Pesaro experience]. Haematologica. 1989;74(5 Suppl):266-70.

11. Walters MC, De Castro LM, Sullivan KM, Krishnamurti L, Kamani N, Bredeson C, et al. Indications and Results of HLA-Identical Sibling Hematopoietic Cell Transplantation for Sickle Cell Disease. Biol Blood Marrow Transplant. 2016;22(2):207-11.
12. Angelucci E, Matthes-Martin S, Baronciani D, Bernaudin F, Bonanomi S, Cappellini MD, et al. Hematopoietic stem cell transplantation in thalassemia major and sickle cell disease: indications and management recommendations from an international expert panel. Haematologica. 2014;99(5):811-20.

13. Gordeuk VR, Castro OL, Machado RF. Pathophysiology and treatment of pulmonary hypertension in sickle cell disease. Blood. 2016;127(7):820-8

14. Johnson FL, Look AT, Gockerman J, Ruggiero MR, Dalla-Pozza L, Billings FT 3rd. Bone-marrow transplantation in a patient with sickle-cell anemia. N Engl J Med. 1984;311(12):780-3.

15. Walters MC, Patience M, Leisenring W, Eckman JR, Scott JP, Mentzer WC, et al. Bone marrow transplantation for sickle cell disease. N Engl J Med. 1996;335(6):369-76.

16. Vermylen C, Cornu G, Ferster A, Ninane J, Sariban E. Bone marrow transplantation in sickle cell disease: the Belgian experience. Bone Marrow Transplant. 1993;12(Suppl 1):116-7.

17. Vermylen C, Cornu G. Bone marrow transplantation for sickle cell anemia. Curr Opin Hematol. 1996;3(2):163-6.

18. Bernaudin F, Souillet G, Vannier JP, Plouvier E, Lemerle S, Michel G, et al Bone marrow transplantation (BMT) in 14 children with severe sickle cell disease (SCD): the French experience. GEGMO. Bone Marrow Transplantat. 1993;12(Suppl 1):118-21.

19. Bernaudin F, Socie G, Kuentz M, Chevret S, Duval M, Bertrand Y, et al. Long-term results of related myeloablative stem-cell transplantation to cure sickle cell disease. Blood. 2007;110(7):2749-56

20. Panepinto JA, Walters MC, Carreras J, Marsh J, Bredeson CN, Gale RP, et al. Matched-related donor transplantation for sickle cell disease: report from the Center for International Blood and Transplant Research. Br J Haematol. 2007; 137(5):479-85.

21. Strocchio L, Zecca M, Comoli P, Mina T, Giorgiani G, Giraldi E, et al. Treosulfan-based conditioning regimen for allogeneic haematopoietic stem cell transplantation in children with sickle cell disease. Br J Haematol. 2015;169(5):726-36.

22. Cappelli BB, Ruggeri F, Labopin A, Volt M, Simoes BP, Ferster A, et al Hematopoietic Stem Cell Transplantation from HLA Identical Sibling For sickle Cell Disease an International Survey on Behalf of EurocordMonacord, EBMT Pediatric Disease Working Party and CIBMTR. Blood. 2015; 126(23):541.

23. Hsieh MM, Fitzhugh CD, Weitzel RP, Link ME, Coles WA, Zhao X, et al Nonmyeloablative HLA-matched sibling allogeneic hematopoietic stem cell transplantation for severe sickle cell phenotype. JAMA. 2014;312(1):48-56.

24. Hsieh MM, Kang EM, Fitzhugh CD, Link MB, Bolan CD, Kurlander R, et al Allogeneic hematopoietic stem-cell transplantation for sickle cell disease. $\mathrm{N}$ Engl J Med. 2009;361(24):2309-17.

25. Fitzhugh CD, Abraham AA, Tisdale JF, Hsieh MM. Hematopoietic stem cell transplantation for patients with sickle cell disease: progress and future directions. Hematol Oncol Clin North Am. 2014 Dec;28(6):1171-85.

26. Bolanos-Meade J, Fuchs EJ, Luznik L, Lanzkron SM, Gamper CJ, Jones RJ, et al. HLA-haploidentical bone marrow transplantation with posttransplant cyclophosphamide expands the donor pool for patients with sickle cell disease. Blood. 2012;120(22):4285-91

27. Lima AR, Ribeiro VS, Nicolau DI. Trends in mortality and hospital admissions of sickle cell disease patients before and after the newborn screening program in Maranhao, Brazil. Rev Bras Hematol Hemoter. 2015;37(1):12-6.

28. Sabarense AP, Lima GO, Silva LM, Viana MB. Survival of children with sickle cell disease in the comprehensive newborn screening programme in Minas Gerais, Brazil. Paediatr Int Child Health. 2015;35(4):329-32. 